\title{
Medicinal Value of Domiciliary Ornamental Plants of the Asteraceae Family
}

\author{
Ishan Saini', Jyoti Chauhan', Prashant Kaushik ${ }^{2,3, *}$ \\ 'Department of Botany, Kurukshetra University Kurukshetra, Kurukshetra, Haryana, INDIA. \\ 2Instituto de Conservación y Mejora de la Agrodiversidad Valenciana, Universitat Politècnica de València, Valencia, SPAIN. \\ ${ }^{3}$ Nagano University, 1088 Komaki, Ueda, Nagano, JAPAN.
}

\begin{abstract}
Gardens are unaccomplished without the showy, pricey investments of ornamental plants. Ornamental plants, especially the flowering plants, have a significant impact on human life. They offer fresh air to the surroundings and release the negativity from the environment. Ornamental plants intrigued humans with their alluring odour and unique. Besides this, many ornamental plants have other economic uses other than just decoration or traditional customs which has been discussed. Many plants are edible and used in several kinds of beverages as medicinal values. Important domiciliary plants that belong to Asteraceae with both ornamental and therapeutic benefits are reviewed in this paper, namely, Calendula, Echinacea, Achillea, Acmella and Tanacetum. These plants possess a high nutritive value and can be cooked or consumed as salads. With numerous pharmaceutical ac-
\end{abstract}

tivities of these plants, we hope that this review will bring awareness for their alternative use.

Key words: Edible flowers, Medicinal ornamental plants, Floriculture, Horticulture, Alkaloids, Essential oil.

\section{Correspondence}

Dr. Kaushik Prashant ${ }^{2,3}$

${ }^{2}$ Instituto de Conservación y Mejora de la Agrodiversidad Valenciana, Universitat Politècnica de València-46022, Valencia, SPAIN.

${ }^{3}$ Nagano University, 1088 Komaki, Ueda, Nagano 386-0031, JAPAN.

Email: prakau@doctor.upv.es

DOI: 10.5530/jyp.2020.12.2

\section{INTRODUCTION}

Ornamental plants can provide multiple profits with regards to environment beauty, economy concern and human lifestyles. ${ }^{1}$ Because of beautiful flowering and lovely attractive foliage, ornamental plants are being grown in homes, workplaces, institutions, etc., to embrace the landscape. ${ }^{2}$ And also floriculture crop products are being exported to countries like the USA, Japan, the UK, Netherlands and Germany. Floriculture has opened an extensive opportunities for jobs, especially to plant breeders. Many flowers like lotus, hibiscus, rose, pionia, sunflower, etc., are used by devotees for spiritual enlightenment to different gods and goddesses. ${ }^{3}$ Growing ornamental trees can help in reducing the temperature. Nyctanthes arbor-tristis, known as night flowering jasmine is a good tree to be in lawns, which have white flowers with orange stalk, being used as 'gajaras', 'poojas' and in Ayurvedic medicines. ${ }^{4}$ Ornamental plants attract pollinators which can feed them through nectar present in their flowers that has high nutritive value for humans too. ${ }^{5}$

Floriculture as a specialized profession, has started in last two decades and is giving tough competition to world trade against other developing countries. Many ornamental plants are being used as indoor for spreading freshness inside homes, hospitals, etc. It has been noted that patient having plants inside their wards recover faster. Plants and flowers have long-term encouraging and constructive effects on human minds. Indoor air pollutants are micro particles that are hard to eliminate physically, but indoor plants can do this tedious job efficiently. ${ }^{6}$ Hedera helix, Nephrolepis exaltata, Anthurium andreanum, Aglaonema modestum, Areca lutescens, Ficusalii, Chrysanthemum leucanthemum, Syngonium podophyllum, Chamaedoraea elegans, Dracena marginata, D. sanderiana, Epipremnumaureum, Clopophytium comosum, Sansevieria trifasciata, Philodendron, Spathiphyllum, etc., are some ornamental indoor plants those have specific volatile substances that can eliminate formaldehyde, ammonia, benzene, xylene, carbon monoxide, chloroform and other toxic compounds in air.

Despite the increasing interest of ornamental plants, some of them are also cultivated for their medicinal use as they have many bioactive compounds like phenolic compounds, carotenoids, antioxidants, essential oils and other secondary metabolites. ${ }^{8,9}$ Ornamental plants like Ocimum sp., Nicotiana sp., Ixora, Aloe vera, Agave, etc. and ornamental flowers like roses, nasturtium, hibiscus, marigold, Calendula, etc. are commonly grown in homes which also have many medicinal applications. Along with this, remedies from plants can be much cheaper and protect against free radicals without any side-effects than medicines formed by pharmaceutical companies. Like Carnations, which has a reputed status as a cut-flower worldwide but the petals of this flower can be used to cure skin problems and to reduce fatigue and stress. Many flowers are edible and can be used for flavouring curry, making sweet-dishes, chutneys, or hot beverages. For example, Japanese Honeysuckle, Woodbine Honeysuckle and Dandelion, have antioxidant properties and can be used for tea or in flavouring syrups with anti-inflammatory assets. ${ }^{10}$ Drinks made from flowers are devoid of caffeine, while other types of teas contain stimulatory drugs such as caffeine, theobromine and xanthenes alkaloid. In Europe, due to the high nutritive values of some edible flowers, hot beverages are served for providing wellness as they having medicinal properties. Lotus and Dahlias are used in making puddings, cupcakes, pastries and other bakery products. Lotus used for lowering blood sugar level, regulate the menstrual cycle and work as an anti-inflammatory agent while Dahlias have antibacterial and antiviral activities. ${ }^{11}$ Ornamental flower-like Tagetes erecta (Family: Asteraceae), mainly used as garden flowers, in garlands, decorating homes, banquets and can be used as an analgesic as well as an antioxidant. ${ }^{12}$ Members of Asteraceae family 
having beautiful yellowish-white flowers used in beverages having antioxidant properties as well as in curing stomach ache. ${ }^{13}$

Herbalists can tell the medical benefits of the particular plant. Some people, may not havea proper degree can understand the benefits of plants growing naturally around them. So this paper is comprised of some of the ornamental plants which are beneficial for medical purpose and other economic uses considering floriculture as a different opportunity to sell more products. Here, we have discussed five medicinal plants of family Asteraceae, namely, Calendula, Echinacea, Achillea, Acmella and Tanacetum.

Following are some ornamental plants discussed which are essential as floral crops plus have medical practicalities.

\section{ORNAMENTAL PLANTS}

\section{CALENDULA OFFICINALIS L. (POT MARIGOLD)}

Family: Asteraceae (Sunflower family)

Main use: Garden flowers

Flowering period: August to November

Scientific Classification

\begin{tabular}{|c|c|}
\hline Kingdom & Plantae \\
\hline Division & Magnoliophyta \\
\hline Class & Magnoliopsida \\
\hline Order & Asterales \\
\hline Family & Asteraceae \\
\hline Genus & Calendula \\
\hline Species & officinalis \\
\hline
\end{tabular}

Calendula which is native to Southern Europe, is herbaceous annual plant mainly grown in late summers to early winters that are highly branched with hairy stem and reaches up to a height of $80 \mathrm{~cm}$. The plant can grow in any soil and needs partial to full sun for flowering. Butterflies and bees are attracted to their dazzling orange flowers. Leaves $(6-15 \mathrm{~cm}$ long) of the plant are alternate, lanceolate, hairy from both sides with wavy margins. The inflorescence is capitulum of $5-8 \mathrm{~cm}$ in diameter, with single row of ray florets at periphery around the central tubular disc florets. Florets are aromatic and give pungent spicy flavour to the food items while the leaves have a bitter taste. Fruits are thorny achene.

Calendula is an ancient plant used as both ornamental in cottage botanical gardens and cemeteries since the $12^{\text {th }}$ century as well as medicinal uses. Calendula officinalis Linn. has a long history of usage by the folklore system, because of rich ethnomedicinal values. Calendula flowers are often used in skincare. ${ }^{14}$ Leaves and flowers are an excellent source of skin diareses and for skin burns. The flowers have also been used as a source of medicinal ingredients, widely used in homoeopathic medicine for the treatment of many diseases for centuries. ${ }^{15} \mathrm{C}$. officinalis has high economic value as herbal medicine and has been approved recently for food use in USA and appears in the Food and Drug Administration (FDA) list of generally recognized as safe (GRAS) substances. ${ }^{16}$ Studies had shown various pharmacological activities viz. nephroprotective, hepatoprotective, hypoglycemic, hypolipidemic, antioxidant potential of C. officinalis in experimental and clinical models. Therefore, the correlation between phytochemical ingredients associated with pharmacological activities needs to establish to maximize their therapeutic applications in mammals. Plants were used by the soldiers during the American Civil War for quick recovery of wounds. Calendula has anti-inflammatory, anti-oede- matous, anti-Tumor-Promoting and anti-oxidative properties. ${ }^{17}$ Europeans use leaves as diaphoretic and resolvent while the floral parts are used as antispasmodic, stimulant and emmenagogue. ${ }^{18}$ The decoction of the flowers was earlier used for treating measles and smallpox and suppression of menstrual flow. ${ }^{19}$ In India, Calendula is often used for curing cut, burns, rashes, dry skin, varicosis and dermatitis..$^{20}$ (20 Maryland, 2011). Sesquiterpenes and saponins extracted from the plant can be used as against viral infection and mutagenic compounds like benzo (a) pyrene. ${ }^{21} \mathrm{~T}$ muurolol, $\alpha$-humulene, $\alpha$-thujene, $\alpha$-terpeneol, $\alpha$-gurjunene, aromadendrene, 1,8-cineole, $\delta$-cadinene, $\gamma$-cadinene, $\beta$-pinene, $\beta$-caryophyllene, Myrcene, Sabinene, Nonanal, Bornyl acetate etc. are other compounds which are extracted from the plant and therapeutically important. ${ }^{22,23}$ Growing Calendulas is very good for the ground-field cover, flowerbed edges and in containers. Some people also make tea by using flowers. The plant is very beneficial for skin repair. Dye also extracted from the flower for colouring fabrics. So it is a critical economic plant to grow. The pharmacological activity of $C$. officinalis is presented in Table 1 .

\section{Antioxidant activity}

Plants are the natural reservoir of antioxidants that inhibit the oxidative stress created as a consequence of the production of free radicals or ROS (reactive oxygen species). Plants produce low molecular weight antioxidant (such as Vitamin C, Vitamin E, phenolic acids, etc.) and high molecular weight secondary metabolites (phytochemicals) against the oxidative stress. These antioxidants are served as a potent free radical scavenger and play a significant role in the treatment of various diseases of humans. Calendula officinalis plant parts also possesses significant antioxidant properties. Aglycon (flavonoids), saponosides, sterol and carotenoids (lipids), isorhamnetin and quercetin (glycosides of flavonol) and organic acids in abundant amount are present in the flowers of this plant. ${ }^{34}$ The Calendula plant extract significantally increased the activity of catalase, glutathione reductase and decreased the glutathione peroxidase activity after oral administration has given to mice for one month. ${ }^{35}$ The butanolic fraction of plant extracts exhibit influential free radical damaging, antioxidant potentiality and provide protection to rat liver microsomes against lipid peroxidation. ${ }^{36}$ The phytochemical constituents of Calendula officinalis extract exhibited high in vitro antioxidant potentiality and DPPH (1, 1-diphenyl 1-2- picrylhydrazyl) induced the ROS scavenging activity along with high reducing capability. ${ }^{37}$ Propylene glycol extracts of the flower head and petals showed that the extract of the petals was found to be more effectual in contrast to the extract of flower head. ${ }^{38}$ Hence the dietary supplements of C. officinalis plant extract act as a source of natural antioxidant and may be used for providing the protection against ageing, cancer, etc. which resulted from the cellular damage created by free radicals.

\section{Anti-inflammatory and analgesic effect of $C$. officinalis}

C. officinalis floral extract exhibited anti-inflammatory effectivity in case of both carrageenins such as histamine, kinins, prostaglandins and dextran such as mast cell degranulation. The interferon- $\gamma$ (IFN- $\gamma)$, histamine, prostaglandins, etc. released into the circulatory system that mediates the inflammatory response of host cell. C. officinalis plant extract decreased the level of (IFN- $\gamma$ ) and also retarded the cyclooxygenase 2 (COX-2) expression which also involved in anti-inflammatory responces. ${ }^{39}$ The plant extract of Calendula significantly reduced the synthesis of reactive oxygen species (ROS) and reactive nitrogen species (RNS). During the chronic inflammation, it also retarded the suppression of neutrophils, eosinophils and macrophages that causes the cell damage. ${ }^{39,40}$ A large amount of flavonoids, carotenoids and lycopene (which served as a potent antioxidant) present in the flowers of $C$. officinalis the lower concentration of lutein flavonoids showed strong inhibitory potential against endogenous reactive oxygen species. ${ }^{41}$ Carotenoids significantly 
inhibit the reactive oxygen species and lycopene greatly reduced the transcription of cytokines. ${ }^{42}$ Caffeic acid, chlorogenic acid and alkylamines contribute the biological activity of E. purpurea. ${ }^{43}$

\section{ECHINACEA PURPUREA (L.) MOENCH. (ECHINACEA)}

\author{
Family: Asteraceae (Sunflower family) \\ Main use: Garden flower, cut-flower \\ Flowering period: April to October
}

\section{Scientific Classification}

\begin{tabular}{|c|c|}
\hline Kingdom & Plantae \\
\hline Division & Magnoliophyta \\
\hline Class & Magnoliopsida \\
\hline Order & Asterales \\
\hline Family & Asteraceae \\
\hline Genus & Echinacea \\
\hline Species & purpurea \\
\hline
\end{tabular}

Echinacea is a herbaceous perennial herb that can grow up to $1.2 \mathrm{~m}$ and is native of North America which was brought to Europe in the late 19's. Flower of the plant can attract birds especially the hummingbirds and butterflies and bees too. Leaves $(16 \times 11 \mathrm{~cm})$ are lanceolate arising from the base of the stem. Echinacea also is known as 'purple coneflower' that prefers soil with neutral $\mathrm{pH}$ and full sun that need less irrigation. Soil type can be rocky, clayey or sandy. With a capitulum inflorescence of $6-13 \mathrm{~cm}$, florets are hermaphroditic purplish-violet with dome-shaped disc floret. ${ }^{44}$

Purple coneflower contains many constituents like polysaccharides, phenolics, caftaric acids, p-coumaric, kaempferol, glycoproteins, p-hydroxybenzoic, protocatechuic acids and the important one, cichoric acids. Along with cichoric acids plant also have rosmarinic acid, 2, 2-diphenyl-1-picrylhydrazyl, flavonoids and otheralkamides. Other alkamides like- isobutylamide, 2-methylbutylamide, nitidanin-diisovalerianate, germacratriene, etc. The plant is used as immunostimulation and immunomodulation, as well as work against the common cold and respiratory infection. Echinacea purpurea plant extract has antibiotic, antiviral, anti-fungal anti-cancerous potential ${ }^{45-48}$ and effectively used against snakebite, toothaches, cold and rabies-like diseases. ${ }^{49}$ E. purpurea roots found to be a potent reservoir of Glycoproteins, alkylamides and polysaccharides that are served as source of immunomodulatory activities. ${ }^{50}$ The root extract of coneflower can be used to up-regulate some genes like- interleukin-7 receptor, Chemokine (C-C motif) ligand-4, T-box transcription factor, integrin, cytohesin-interacting protein, intercellular adhesion molecule-1, etc., which are involved in cell immune system. Interestingly, the plant has a mosquitocidal property. ${ }^{51,52}$

Echinacea is a plant used for ornamental purpose perfect for small gardens as flowerbeds, or alongside curbs/walkways. It is a beneficial plant in gardens having unique floral shapes. Echinacea is also being noted to fight against diseases of ornamental fishes as noted in Poecilia reticulata. So it is advised to have coneflower supplement in fish diet to increase the aquaculture production. The plant can also improve the human immune system and also be added as $\mathrm{n}$ diet supplement. ${ }^{53}$

\section{Immunomodulatory effects}

Echnicea purpurea plant extract stimulates the functioning of the immune system such as the activation of phagocytotic activities, stimulation of fibroblast cells and increased activities of respiratory system as a consequence of which the leukocyte mobility intensified. ${ }^{49}$ The plant extract of E. purpurea enhanced the innate immunity of the organisms against the attack of pathogen by the activation of working of macrophages, natural killer (NK) cells, neutrophils and polymorphonuclear leukocytes $(\mathrm{PMN})^{54}$ and due to this reason this plant is widely used for the treatment of chronic pelvic infection, disease of respiratory system and wound infection. ${ }^{55,56}$ The immunostimulatory and anti-inflammatory activities of $E$. purpurea mainly depends on the presence of alkamides, caffeic acid derivatives, glycoproteins, ketoalkenes and polysaccharides. ${ }^{54}$

\section{Anti-inflamatory effects}

The ethanolic extract of aerial plant parts and roots of the Echinacea purpurea strongly reduced the concentration of collagen proteins that is induced by fibroblast cells. ${ }^{57}$ The extract of dried root of E. purpurea given to mice, effectually retarded the Carrageenan- promoted paw edema ${ }^{58}$ and this response may be associated with the suppression of COX-1 and COX-2 by the functioning of alkamides..$^{59}$

\section{Phytochemical constituents}

The Alkamides, amides, caffeic acid derivatives and polysaccharides are the main secondary metabolites which have isolated from the plant extract of Ecinacea purpurea. The HPLC-MS analysis strongly advocated the presence of cichoric acid and alkamide content in the plant extract. ${ }^{60}$ The alkaloids, quercetin, kaempferol, isorhamnetin (flavonoids), heterogenous polysaccharides, $\mathrm{p}$-coumaric, $\mathrm{p}$-hydroxybenzoic, protocatechuic acids (phenolic compounds) polyacetylenes, arabinogalactan protein and inulin type fraction were isolated from the juicy extract of aerial plant parts..$^{54,61,62}$

\section{Antioxidant properties}

The free radical destroying properties of the E. purpurea root extract was found to be associated with the cichoric acid and phenolic contents of this plant..$^{63}$ The alkamide content of this plant remains inoperative against the free radicals. ${ }^{64,65}$ Cichoric acid acts as potent free radical scavenger and alkamides have not showed free radical destroying activities but increased the functioning of cichoric acid by regenerating the cichoric acids by donating the allylic hydrogen. ${ }^{65,66}$

\section{ACMELLA OLERACEA (L.) (TOOTHACHE PLANT)}

Family: Asteraceae (Sunflower family)

Main use: Garden flower, Herbal medicine

Flowering period: August to October

\section{Scientific Classification}

\begin{tabular}{|c|c|}
\hline Kingdom & Plantae \\
\hline Division & Magnoliophyta \\
\hline Class & Magnoliopsida \\
\hline Order & Asterales \\
\hline Family & Asteraceae \\
\hline Genus & Acmella \\
\hline Species & officinalis \\
\hline
\end{tabular}

Acmella oleracea (L.) (synonyms Spilanthes acmella Murr. or Spilanthes oleracea L.) is used as garden herbal medicines the it is used traditionally for medical purpose, especially for toothache. Chewing A. oleracea is a memorial experience that gives a strong prickling taste to the tongue. It's a very unusual garden plant that looks pretty and is very easy to manage. It is believed to be native of Brazil, but its origin is not clear yet (flow- 
ers of india.net). Acmella is generally regarded as annual. The stem of the plant is smooth, reddish-green and generally prostrate $(25-30 \mathrm{~cm})$. Leaves are ovate with toothed margin and sharp tip. Floral heads arise singly primarily with numerous yellowish-orange disc florets. The plant can flourish in acid to neutral well-drained soil that needs moderate sunlight. ${ }^{67}$

Acmella is known for its anti-viral, anti-malarial, anthelminthic, antinociception, anti-bacterial, anti-hyperalgesic, anti-fungal, anti-inflammatory, insecticidal and analgesic effects. Acmella has other important properties also viz. diuretic, immunomodulatory, anti-oxidant, antihepatoxic, aphrodisiac and vasorelaxant. Acmella is also used against gastrointestinal troubles, including ulcers. The decoction of root can also be used as purgative. Spilanthol is the crucial alkaloid present in the plant along with cinnamaldehyde, capsaicin, stigmasteryl-3-O-bD-glucopyranoside allyl isothiocyanate and other trienoic-acid isobutyl amides. The plant also has vanillic acid, 3 -acetylaleuritolic acid, scopoletin, $\beta$-sitostenone, $\beta$-amyrinester, $\beta$-caryophyllene, $\gamma$-cadinene, thymol, miricilic alcohol glycosides, germacrene, trans-isoferulic and trans-ferulic acid. The floral parts and leaves of the plant contains vitamin C, phenolic compounds, polyamines, carotenoids and peroxidase activity that constitute to anti-oxidants. Acmella is also effective against malaria. ${ }^{68}$ The aqueous extract of aerial parts of $A$. oleracea showed antipyretic effectivity against Saccharomyces cerevisiae that induced pyrexia; thereby it used as a potent remedy for high fever. ${ }^{69}$ It is used as an insecticide against the pest Tuta absoluta. ${ }^{70}$

Acmella plant is an essential herbal plant that gives spicy tingling taste at once and then numb after sometimes. Along with curing toothache, the plant is also used for relaxing joint and muscle aches, improves muscle tiredness and relieve healing rashes on the legs. The pungent aftertaste may remain for an hour that is an excellent analgesic used by local people since time immemorial. Acmella is used by Africans and Indian for curing throat and gum infection, liver abscess, stomatitis and malaria. In countries like Mauritius, Madagascar, India, etc., leaves of A. oleracea is used as a vegetable. ${ }^{71}$ The most common cultured species is commonly used in Africa and India as a traditional folk medicine to cure toothache, throat complaint, stomatitis and malaria. The pharmacological activity of Acmella oleracea is presented in Table 2. The usage of Acmella oleracea in different ethnopharmacological surveys is presented in Table 3. Whereas, the detailed analysis of root and leaf phytochemicals are presented in Table 4.

\section{TANACETUM PARTHENIUM (L.) SCH. BIP. (FEVERFEW)}

Family: Asteraceae (Sunflower family)

Main use: Garden flower, dried-flower arrangements

Flowering period: July and August

\section{Scientific Classification}

\begin{tabular}{|c|c|}
\hline Kingdom & Plantae \\
\hline Division & Magnoliophyta \\
\hline Class & Magnoliopsida \\
\hline Order & Asterales \\
\hline Family & Asteraceae \\
\hline Genus & Tanacetum \\
\hline Species & parthenium \\
\hline
\end{tabular}

Table 1: Phytochemical constituents present in the different plant parts of $C$. officinalis $L$.

\begin{tabular}{|c|c|c|c|}
\hline Plant part & Phytochemicals & Active principle & References \\
\hline & Coumarins & Esculetin, scopoletin, umbelliferone & Kerkach et al. $1986^{24}$ \\
\hline & Flavonoids & Isoquercitrin, rutin, calendoflavoside & Ukiya et al. $2006^{17}$ \\
\hline & & Quercetin, Isorhamnetin & Kurkin et al. $2007^{25}$ \\
\hline & & Isorhamnetin-3-O- $\beta-\mathrm{D}$ glycoside, & Vidal-Ollivier et al.1989 26 \\
\hline & & Narcissin & \\
\hline & Terpinoids & Calenduloside & Vecherko et al. $1975^{27}$ \\
\hline & & Calendula glycoside A, Calendula & Ukiya et al. $2006^{17}$ \\
\hline & & glycoside B & Naved et al. $2005^{28}$ \\
\hline & & Cornulacic acid acetate & Wojciechowski et al. $197^{29}$ \\
\hline \multirow[t]{10}{*}{ Flowers } & & Erythrodiol & Zitterl-eglseer et al.1997 15 \\
\hline & & Lupeol, Y -taraxasteol & \\
\hline & Volatile oils & Cubenol, & Nicoletta et al. $2003^{30}$ \\
\hline & & a-cadinol, & \\
\hline & & oplopanone, methyllnoleate & \\
\hline & & Sabinene, limonene, & \\
\hline & & a-pinene, p-cymene, nonanal, & \\
\hline & & carvacrol, & Khalid et al. $2012 .^{31}$ \\
\hline & & geraniol, nerolidol, & \\
\hline & & t-muurolol, palustron & \\
\hline \multirow[t]{2}{*}{ Leaves } & Quinones & Phylloquinone, & Janiszowska et al. $1976^{32}$ \\
\hline & & $\begin{array}{l}\text { a-tocopherol, ubiquinone, } \\
\text { plastoquinone }\end{array}$ & \\
\hline Root & Terpenoid & Calenduloside B & Iatsyno et al. $1978^{33}$ \\
\hline
\end{tabular}


Feverfew is a perennial bushy herb that grows up to a height of $60-65 \mathrm{~cm}$ having pungently-scented (citrus) leaves. The plant spread rapidly and produces daisy-like inflorescence with white-coloured ray and yellowcoloured disc florets. Many cultivars of Tanacetum are being developed for ornamental purpose. Feverfew is very good for relieving headache. The plant is native of Eurasia but later cultivation is spread to North America, Chile and rest of the world. The plant is drought tolerant that need less moisture but good aerated loamy acidic to alkaline soil under full sun. The yellow colour of the flower also attracts lots of butterflies and hummingbirds. Leaves are yellowish-green, hairless and pinnately dissected as in Chrysanthemum. ${ }^{84}$

Traditionally, feverfew is being used for treating headache, fever, common cold, diarrhoea, anaemia digestive problems, liver diseases and arthritis. Tanacetum has many pharmacologic properties such as antiinflammatory, anti-cancer, anti-spasmodic, cardiotonic, as an emmenagogue and as an enema for worms. Numerous compounds have been extracted from the plants namely- canin, artemorin, santamarine, costunolide, manolialide, artecanin, balchanin, reynosin, 3-beta-hydroxyparthenolide, secotanaparthenolide B, 3-beta-hydroxycostunolide, 10-epicanin, epoxysantamarine, 8-beta hydroxyreynosinn, secotanapar- thenolide A, 83, 4-beta-epoxy-8-deoxycumambrin B -alpha-hydroxyestagiatin, 1-beta-hydroxyarbusculin, epoxyartemorin and tanaparthinalpha-peroxide. Parthenolide is a significant alkaloid present in fewerfew along with other volatile oils viz. camphor, p-cymene, camphene, bornyl acetate $\alpha$-terpineol, eugenol, $\alpha$-terpinene, isobornyl 2-methyl butanoate, $\alpha$-phellandrene, tricylene, $\gamma$-terpinene, myrtenal, $\alpha$-thujene, $\rho$-cymen8-ol, carvacrol, pinocarvone, borneol, $\alpha$-pinene, trans-myrtenol acetate, chrysantheone, terpinen-4-ol, $\beta$-pinene and caryophyllene oxide and many others. ${ }^{85,86}$

Tanacetum plant deserves a spot in every garden due to its daisy appearance and bright coloured flowers. It is a good bedding plant that is used in rock gardens, cottages and along borders. The plant has long traditional medicinal properties which are also being used in Christmas trees. ${ }^{87}$

The pharmacological activity of Tanacetum partheniumis leaf extract is presented in Table 5.

Preliminary analysis of phytochemical constituent showed the presence of Alkaloids, carbohydrates, flavonoids, saponins, steroids and terpenoids but not showed the presence of tannins. ${ }^{88,89}$

Table 2: Pharmacological activity of Acmella oleracea (L.) R.K. Jansen.

\begin{tabular}{|c|c|c|c|c|}
\hline $\begin{array}{l}\text { Pharmacological } \\
\text { action }\end{array}$ & Plant part utilized & $\begin{array}{c}\text { Experimentation } \\
\text { model }\end{array}$ & $\begin{array}{l}\text { Experimental } \\
\text { animal }\end{array}$ & References \\
\hline Anaesthetic & Whole plant & $\begin{array}{l}\text { Plexus anaesthesia in } \\
\text { frog }\end{array}$ & Frog & Narayana et al..$^{72}$ \\
\hline Antipyretic action & Whole plant & Yeast induced pyrexia & Albino rat & Narayana et al..$^{72}$ \\
\hline $\begin{array}{l}\text { Anti-inflamatory } \\
\text { activity }\end{array}$ & Whole plant & $\begin{array}{c}\text { Carrageenan activated } \\
\text { paw oedema }\end{array}$ & Albino rat & $\begin{array}{c}\text { Ratansooriya et al. } 2004^{73} \\
\text { Wu et al. } 2008^{74}\end{array}$ \\
\hline Anti-fungal activity & Flowers & - & - & Moreira et al. $1989^{75}$ \\
\hline Diuretic activity & $\begin{array}{l}\text { Flowers and whole } \\
\text { plant }\end{array}$ & $\begin{array}{l}\text { induction of dieresis } \\
\text { (cold water extract) }\end{array}$ & Albino rat & $\begin{array}{l}\text { Peiris et al. } 2001 ;^{76} \\
\text { Mondal et al. } 1998^{77}\end{array}$ \\
\hline Anti-oxidant activity & Leaves and whole plant & $\begin{array}{l}\text { SOD and DPPH } \\
\text { method }\end{array}$ & $\begin{array}{l}\text { In-vitro, no } \\
\text { animal used }\end{array}$ & $\begin{array}{l}\text { Ahmed et al. } 2004 ;^{78} \\
\text { Wu et al. } 2008^{74}\end{array}$ \\
\hline $\begin{array}{l}\text { Antimalarial and } \\
\text { larvicidal activity }\end{array}$ & $\begin{array}{l}\text { Spilanthol (extracted } \\
\text { from the entire plant) }\end{array}$ & - & $\begin{array}{l}\text { Egg and pupae of } \\
\text { vector }\end{array}$ & Saraf and Dixit $2002^{79}$ \\
\hline $\begin{array}{c}\text { Immunomodulatory } \\
\text { effect }\end{array}$ & Whole plant & - & Mice & Sharma et al. $2012^{80}$ \\
\hline
\end{tabular}

Table 3: Usage of Acmella oleracea in different ethnopharmacological surveys.

\begin{tabular}{|c|c|c|c|}
\hline $\begin{array}{l}\text { Country/ } \\
\text { Geographic } \\
\text { Area }\end{array}$ & Plant part & Utilization & References \\
\hline Bangladesh & $\begin{array}{l}\text { Leaves and } \\
\text { Flowers }\end{array}$ & $\begin{array}{l}\text { Headache, toothache, } \\
\text { muscle pain, cough, }\end{array}$ & Tiwari et al. $2011^{81}$ \\
\hline Brazil & Leaves & $\begin{array}{l}\text { Aginst alcoholic } \\
\text { hangover }\end{array}$ & Dubey et al. $2013^{68}$ \\
\hline India & $\begin{array}{l}\text { Leaves and } \\
\text { Flowers }\end{array}$ & $\begin{array}{l}\text { Antitoothache and } \\
\text { throat infection, } \\
\text { insecticidal, Gastro- } \\
\text { intestinal disorders }\end{array}$ & Pathak,K. $2013^{82}$ \\
\hline Indonesia & $\begin{array}{l}\text { Whole } \\
\text { plant }\end{array}$ & Anticancerous agent & $\begin{array}{l}\text { Reshmi and } \\
\text { Rajalakshmi, } \\
2016^{83}\end{array}$ \\
\hline Sri Lanka & $\begin{array}{l}\text { Flower } \\
\text { extract }\end{array}$ & $\begin{array}{l}\text { Stimulate salivary } \\
\text { gland tissues }\end{array}$ & Paulraj et al. $2013^{67}$ \\
\hline
\end{tabular}

Table 4: Analysis of phytochemical constituents from aqueous extract of leaf and root of Acmella oleracea (L.) R.K. Jansen.

\begin{tabular}{ccc}
\hline Phytochemical & $\begin{array}{c}\text { Aqueous extract of } \\
\text { leaf }\end{array}$ & $\begin{array}{c}\text { Aqueous extract of } \\
\text { root }\end{array}$ \\
\hline Alkaloids & present & present \\
Amino acids & absent & absent \\
Carbohydrate & present & present \\
Carotenoids & present & absent \\
Flavonoids & absent & absent \\
Glycosides & absent & absent \\
Steroids & absent & absent \\
Tannins & present & present \\
\hline
\end{tabular}


Table 5: Analysis of phytochemical constituents from aqueous and ethanolic leaf extracts of Tanacetum parthenium.

\begin{tabular}{ccc|}
\hline Phytochemicals & $\begin{array}{c}\text { Aqueous extract } \\
\text { of leaf }\end{array}$ & $\begin{array}{c}\text { Ethanolic extract of } \\
\text { leaf }\end{array}$ \\
\hline $\begin{array}{c}\text { Alkaloids(Mayers/ } \\
\text { Wagner's/ Dragendorff } \\
\text { reagent) }\end{array}$ & present & present \\
$\begin{array}{c}\text { Carbohydrate(Fehlings+ } \\
\text { Benedict's test) }\end{array}$ & present & present \\
Flavonoids & present & present \\
Saponins & present & present \\
Steroids (Libermann's / & present & present \\
Salkowski test) & absent & absent \\
Tannins & present & present \\
Terpenoids & & \\
\hline
\end{tabular}

\section{Anti-inflammatory activities}

Genus Tanacetum act as an inhibitor of prostaglandin biosynthesis. The aerial plant extract retarded the production of prostaglandin. Sesquiterpene lactones, abundantly present in chloroform leafy extract of this plant and significantly decreased the biosynthesis of prostaglandins in mice and human being. The lipophilic compounds found to be associated with the anti-inflammatory function as it retarded the oxidative activities of neutrophil cells of the human being. ${ }^{90-92}$ A lipophilic flavonoid (obtained from leaf, flower and seeds of this plant) called as Tanetin, inhibit the production of prostaglandin.

\section{Chemotherapeutic effect and anticancerous effect}

Parthenolide (a sesquiterpene lactone of feverfew) retarded the growth and development of bacteria, yeast and the various filamentous fungi ${ }^{93}$ and also act as a significant inhibitor of Mycobacterium tuberculosis and M. avium. ${ }^{94}$ The lactone compounds, more importantly, parthenolide exhibited the anticancerous effectivity and significantly reduced the functioning of fibroblast cells, laryngeal carcinoma, epidermoid cancer of the nasopharyngeal cavity of human being, also retarded the anti-EpsteinBarr early antigen function. ${ }^{95-97}$

\section{CONCLUSION}

We can conclude that there is a number of ornamental plans which be used both as decoration and medical purpose as the majority of them are having antioxidant activity and can be taken in many types of beverages. Flowers of many ornamental plants are used in cooking having essential oil and alkaloids, which add a different flavour to the food. Several ornamental plants can be used as indoor plants for the removal of toxic compounds in the air inside the home, hospitals, etc. Many flowers and leaves of ornamental plants are eaten as raw in salads or can be used as garnishing curry. Many flowers like lavender, rose, chamomile, hibiscus, etc. are having sweet fragrance and can be used in perfumes, soaps, oils, etc. Many ornamental plants are being used local people for making of syrups or juices or teas for getting anti-oxidants directly from the plants. Many nurseries are promoting to sell their hybrid varieties which can serve both purposes ornamental as well as medicinal. It can be suggested that we should grow some amount of ornamental plants in our surroundings to make it pleasant and to feel calmness. There are so many plants which can be consumed directly but their right properties and quantity should be known. As they are devoid of any side-effects so can be used easily by the general public. There are lots of magic hidden in flowers which have to be discovered yet. Future prospective of growing these ornamental plants can be vast as they not only serve an ornamental purpose but also used for commercial medicinal purpose.

\section{ACKNOWLEDGEMENT}

Authors are thankful to the anonymous reviewers for their careful reading of the manuscript and for providing insightful suggestions.

\section{CONFLICT OF INTEREST}

There are no conflicts of interest.

\section{REFERENCES}

1. lersel MWV, Chappell MR, Thomas PA. Optimizing growth, quality and profits through precision irrigation in ornamental plant production. In: III International Conference on Quality Management in Supply Chains of Ornamentals. 2015;1131:57-64.

2. Milstein GP. The uses and potential of wildflower seed in landscaping. Flower seeds: Biology and technology. Columbus (OH): CABI Publishing. 2005;39-51.

3. De L. Improvement of Ornamental Plants: A Review. Int J Hort. 2017;7:180-204.

4. Shrivastava R, Bharadwaj AK. Nyctanthes arbortristis an Important Medicinal Plant of Madhya Pradesh State: A Review. UK J Phar Bios. 2018;6(6):10-5.

5. Hicks DM, Ouvrard P, Baldock KCR, Baude M, Goddard MA, Kunin WE, et al. Food for Pollinators: Quantifying the Nectar and Pollen Resources of Urban Flower Meadows. PLoS One. 2016;11(6):1-25.

6. Kennedy DO, Wightman EL. Herbal extracts and phytochemicals: Plant secondary metabolites and the enhancement of human brain function. Advances Nutrition. 2011;2(1):32-50

7. Wei X, Lyu S, Yu Y, Wang Z, Liu H, Pan D, et al. Phylloremediation of Air Pollutants: Exploiting the Potential of Plant Leaves and Leaf-Associated Microbes. Front Plant Sci. 2017;8:1-25. Available from: https://www.ncbi.nlm.nih.gov/pmc/ articles/PMC5532450/

8. Goleniowski M, Bonfill M, Cusido R, Palazón J. Phenolic Acids. In: Natural Products. Springer, Berlin, Heidelberg. 2013;1951-73.

9. Kaushik P, Andújar I, Vilanova S, Plazas M, Gramazio P, Herraiz FJ, et al. Breeding Vegetables with Increased Content in Bioactive Phenolic Acids. Molecules. 2015;20(10):18464-81.

10. Alamgir ANM. Introduction: Therapeutic Use of Medicinal Plants and Their Extracts: Pharmacognosy. Cham: Springer International Publishing. 2017;1:1-17.

11. Grumezescu A, Holban AM. Nutrients in Beverages: The Science of Beverages. Academic Press. 2019;12:656-89.

12. Jakubczyk K, Janda K, Watychowicz K, Łukasiak J, Wolska J. Garden nasturtium (Tropaeolum majus L.): A source of mineral elements and bioactive compounds. Rocz Panstw Zakl Hig. 2018;69(2):119-26.

13. Mahomoodally MF. Traditional Medicines in Africa: An Appraisal of Ten Potent African Medicinal Plants. Evidence-Based Complementary and Alternative Medicine. 2013;1:1-14.

14. Muley BP, Khadabadi SS, Banarase MNB. Phytochemical constituents and pharmacological activities of Calendula officinalis Linn (Asteraceae): A Review. Tropical J Pharm Res. 2009;8(5):455-65.

15. Zitterl-eglseer K, Sosa S, Jurenitsch J, Schubert-Zsilavecz M, Della LR, Tubaro $A$, et al. Anti-oedematous activities of the main triterpendiol esters of marigold (Calendula officinalis L.). J Ethnopharmacol. 1997;57(2):139-44

16. Gazim ZC, Rezende CM, Fraga SR, Svidzinski TI, Cortez DA. Antifungal activity of the essential oil from Calendula officinalis L. (asteraceae) growing in Brazil. Braz J Microbiol. 2008;39(1):61-3.

17. Ukiya M, Akihisa T, Yasukawa K, Tokuda H, Suzuki T, Kimura Y. Anti-inflammatory, anti-tumor-promoting and cytotoxic activities of constituents of marigold (Calendula officinalis) flowers. J Nat Prod. 2006;69(12):1692-6.

18. Kirtikar KR, Basu BD. Indian Medicinal Plants. Deharadun, India, International Book Distributor. 1993;2:1413-4.

19. Khare CP. Encyclopedia of Indian Medicinal Plants. Germany, Springer-Verlag Publisher. 2004;116-7.

20. Arora D, Rani A, Sharma A. A review on phytochemistry and ethnopharmacological aspects of genus Calendula. Pharmacognosy Reviews. 2013;7(14):179.

21. Detommasi N, Pizza C, Conti C, Orsi N, Stein ML. Structure and in vitro antiviral activity of sesquiterpene glycosides from Calendula arvensis. J Nat Prod. 1990;53(4):830-5

22. Okoh OO, Sadimenko AP, Asekun OT, Afolayan AJ. The effects of drying on the chemical components of essential oils of Calendula officinalis L. Afr J Biotechnol. 2008;7(10):1500-2.

23. Butnariu M, Coradini CZ. Evaluation of biologically active compounds from $\mathrm{Ca}$ lendula officinalis flowers using spectrophotometry. Chem Cent J. 2012;6(1):35. 
24. Kerkach Al, Komissarenko NF, Chernobai VT. Coumarines of the inflorescences of Calendula officinalis and Helichrysum arenarium. Chem Nat Compd. $1986 ; 22: 722-3$.

25. Kurkin VA, Sharova OV. Flavonoids from Calendula officinalis flowers. Khim Prir Soed. 2007;2:179-80.

26. Vidal-Ollivier E, Balansard G. Revised structures of triterpenoid saponins from the flowers of Calendula officinalis. J Nat Prod. 1989;52(5):1156-9.

27. Vecherko LP, Sviridov AF, Zinkevich EP, Kogan LM. The structure of calenduloside C and D from the roots of Calendula officinalis. Khim Prir Soed. 1975;11(3):36673.

28. Naved T, Ansari SH, Mukhtar HM, Ali M. New triterpenic esters of oleaneneseries from the flowers of Calendula officinalis Linn. Med Chem. 2005;44:108891.

29. Wojciechowski Z, Jelonkiewicz-Konador A, Tomaszewski M, Jankowski J, Kasprzyk Z. The structure of glucosides of oleanolic acid isolated from the roots of Calendula officinalis flowers. Phytochem. 1971;10(5):1121-4.

30. Nicoletta CB, Marongiu PA, Pivetta T, Procedda S. Extraction, separation and isolation of volatiles and dyes from Calendula officinalis L. and Aloysia trphylla (L'Her) britton by supercritical CO . J Essent Oil Res. 2003;15(4):272-7.

31. Khalid KA, Teixeria DSJA. Biology of Calendula officinalis Linn.: Focus on pharmacology, biological activities and agronomic practices. Med Aromat Plant Sci Biotechnol. 2012;6(1):12-27.

32. Janiszowska W, Michalski W, Kasprzyk Z. Polyprenyl quinines and a-tocopherol in Calendula officinalis. Phytochem. 1976;15(1):125-7.

33. latsyno Al, Belova LF, Lipkina GS, Sokolov SI, Trutneva EA. Pharmacology of calenduloside $B$, a new triterpene glycoside from the roots of Calendula officinalis. Farmakol Toksikol. 1978;41(5):556-60.

34. Saleem M, Zaka S. Studies on marigold seed oil and seed meal. Fette Seifen Anstrichmittel. 1986;88(5):178-80.

35. Preethi KC, Kuttan G, Kuttan R. Antioxidant potential of an extract of Calendula officinalis flowers in vitro and in vivo. Pharm Biol. 2006;44(9):691-7.

36. Cordova CA, Siqueira IR, Netto CA, Yunes RA, Volpato AM, Cechinel FV. Protective properties of butanolic extract of the Calendula officinalis L. (marigold) against lipid peroxidation of rat liver microsomes and action as free radical scavenger. Redox Rep. 2002;7(2):95-102.

37. Verma PK, Raina R, Sultana M. Phytochemical constituents and antioxidant potential in floral extracts of Calendula officinalis Linn. World J Pharmaceutical Res. 2014;3:2067-83.

38. Frankic T, Salobir K, Salobir J. The comparison of in-vivo antigenotoxic antioxidative capacity of two propylene glycol extracts of Calendula officinalis (Marigold) and vitamin E in young growing pigs. J Anim Physiol Anim Nutr. 2008;40:1-7.

39. Preethi KC, Kuttan G, Kuttan R. Anti-inflammatory activity of flower extract of Calendula officinalis Linn. and its possible mechanism of action. Indian J Exp Biol. 2009;47:113-20.

40. Iles KE, Forman HJ. Macrophage signaling and respiratory burst. Immun Res. 2002;591:123.

41. Nishino H, Murakosh M, li T, Takemura M, Kuchide M, Kanazawa M. Carotenoids in cancer chemoprevention. Cancer Metast Rev. 2002;21(3-4):257-64.

42. Della LR. Topical anti-inflammatory activity of Calendula officinalis extracts. Planta Med. 1990;56(06):658.

43. Kumar KM, Ramaiah S. Pharmacological importance of Echinacea purpurea. Int J Pharm Biol Sci. 2011;2(4):305-14

44. LiTS. Echinacea: Cultivation and medicinal value. Hort Technol. 1998;8(2):122-9.

45. Chicca A, Adinolfi B, Martinotti E, Fogli S, Breschi MC, Pellati F, et al. Cytotoxic effects of Echinacea root hexanic extracts on human cancer cell lines. J Ethnopharmacol. 2007;110(1):148-53.

46. Dong L, Wang H, Niu J, Zou M, Wu N, Yu D. Echinacoside induces apoptotic cancer cell death by inhibiting the nucleotide pool sanitizing enzyme MTH1. Onco Targets Ther. 2015;8:3649-64.

47. Kim HR, Oh SK, Lim W, Lee HK, Moon BI, Seoh JY. Immune enhancing effects of Echinacea purpurea root extract by reducing regulatory $T$ cell number and function. Nat Prod Commun. 2014;9(4):511-4.

48. Pellati F, Epifano F, Contaldo N, Orlandini G, Cavicchi L, Genovese S. Chromatographic methods for metabolite profiling of virus- and phytoplasma-infected plants of Echinacea purpurea. J Agric Food Chem. 2011;59(19):10425-34.

49. World Health Organization. WHO monographs on selected medicinal plants. 1999;1:136-45.

50. Balciunaite G, Juodsnukyte J, Savickas A, Ragazinskiene O, Siatkute L, Zvirblyte G. Fractionation and evaluation of proteins of Echinacea purpurea (L.) Moench. Acta Pharm. 2015;65:473-9.

51. Bauer R. ACS Symposium Series 691 (Phytomedicines of Europe: Chemical and biological activity). American Chemical Society; Washington, DC. 1998;40-157.

52. Manayi A, Vazirian M, Saeidnia S. Echinacea purpurea: Pharmacology, phytochemistry and analysis methods. Pharmacogn Rev. 2015;9(17):63-72.

53. Guz L, Sopinska A, Oniszczuk T. Effect of Echinacea purpurea on growth and survival of guppy (Poecilia reticulata) challenged with Aeromonas bestiarum. Aquacult Nutr. 2011;17(6):695-700.
54. Barnes J, Anderson LA, Gibbons S, Phillipson JD. Echinacea species (Echinacea angustifolia (DC.). Hell Echinacea pallida (Nutt.) Nutt Echinacea purpurea (L.) Moench): A review of their chemistry, pharmacology and clinical properties. $J$ Pharm Pharmacol. 2005;57(8):929-54.

55. Grimm W, Muller HH. A randomized controlled trial of the effect of fluid extract of Echinacea purpurea on the incidence and severity of colds and respiratory infections. Am J Med. 1999;106(2):138-43.

56. Patel T, Crouch A, Dowless K, Freier D. Acute effects of oral administration of a glycerol extract of Echinacea purpurea on peritoneal exudate cells in female swiss mice. Brain Behav Immun. 2008;22:29-39.

57. Zoutewelle G, Wijk RV. Effects of Echinacea purpurea extracts on fibroblast populated collagen lattice contraction. Phytother Res. 1990;4(2):77-81.

58. Raso GM, Pacilio M, DiCarlo G, Esposito E, Pinto L, Meli R. In-vivo and in-vitro anti-inflammatory effect of Echinacea purpurea and Hypericum perforatum. J Pharm Pharmacol. 2002;54(10):1379-83.

59. Clifford LJ, Nair MG, Rana J, Dewitt DL. Bioactivity of alkamides isolated from Echinacea purpurea (L.). Moench Phytomed. 2002;9(3):249-53.

60. Luo XB, Chen B, Yao SZ, Zeng JG. Simultaneous analysis of caffeic acid derivatives and alkamides in roots and extracts of Echinacea purpurea by high-performance liquid chromatography-photodiode array detection-electrospray mass spectrometry. J Chromatogr A. 2003;986(1):73-81.

61. Bohlmann F, Hoffmann H. Further amides from Echinacea purpurea. Phytochem. 1983;22:1173-75

62. Classen B, Witthohn K, Blaschek W. Characterization of an arabinogalactan-protein isolated from pressed juice of Echinacea purpurea by precipitation with the beta-glucosyl Yariv reagent. Carbohydr Res. 2000;327(4):497-504.

63. Hu C, Kitts DD. Studies on the antioxidant activity of Echinacea root extract. J Agric Food Chem. 2000;48(5):1466-72.

64. Orhan I, Senol FS, Gülpinar AR, Kartal M, Sekeroglu N, Deveci M, et al. Acetylcholinesterase inhibitory and antioxidant properties of Cyclotrichium niveum Thymus praecox subsp. caucasicus var. caucasicus, Echinacea purpurea and E. pallida. Food Chem Toxicol. 2009;47(6):1304-10.

65. Thygesen L, Thulin J, Mortensen A, Skibsted LH, Molgaard P. Antioxidant activity of cichoric acid and alkamides from Echinacea purpurea alone and in combination. Food Chem. 2007;101(1):74-81.

66. Becker EM, Nissen L, Skibsted LH. Antioxidant evaluation protocols: Food quality or health effects. Europ Food Res Technol. 2004;219(6):561-71.

67. Paulraj J, Govindarajan R, Palpu P. The genus Spilanthes ethnopharmacology, phytochemistry and pharmacological properties: A review. Adv Pharmacol Sci. 2013;68:1-22.

68. Dubey S, Maity S, Singh M, Saraf SA, Saha S. Phytochemistry, Pharmacology and Toxicology of Spilanthes acmella: A review. Adv Pharmacol Sci. 2013;19:210.

69. Chakraborty A, Devi BR, Sanjebam R, Khumbong S, Thokchom IS. Preliminary studies on local anesthetic and antipyretic activities of Spilanthes acmella Murr. in experimental animal models. Indian J Pharmacol. 2010;42(5):277-9.

70. Moreno SC, Carvalho GA, Picanço MC, Morais EG, Pereira RM. Bioactivity of compounds from Acmella oleracea against Tuta absoluta (Meyrick) (Lepidoptera: Gelechiidae) and selectivity to two non-target species. Pest Management Sci. 2012;68(3):386-93.

71. Prachayasittikul V, Prachayasittikul S, Ruchirawat S, Prachayasittikul V. High therapeutic potential of Spilanthes acmella: A review. Excli J. 2013;12:291-12.

72. Narayana KR, Reddy MS, Chaluvadi MR, Krishna DR. Bioflavonoids classification, pharmacological, biochemical effects and therapeutic potential. Indian $\mathrm{J}$ Pharmacol. 2001;33(1):2-16.

73. Ratnasooriya WD, Pieris KPP, Samaratunga U, Jayakody JRAC. Diuretic activity of Spilanthes acmella flowers in rats. J Ethnopharmacol. 2004;91(2-3):317-20.

74. Wu LC, Fan NC, Lin MH, Chu IR, Huang SJ, Hu CY, et al. Antiinflammatory effect of spilanthol from Spilanthes acmella on murine macrophage by down-regulating LPS-induced inflammatory mediators. J Agric Food Chem 2008;56(7):2341-9.

75. Moreira VM, Maia JG, DeSouza JM, Bortolotto ZA, Cavalheiro EA. Characterization of convulsions induced by a hexanic extract of Spilanthes acmella var oleracea in rats. Braz J Med Biol Res. 1989;22(1):65-7.

76. Peiris KPP, Silva GKJ, Ratnasooriya WD. Analgesic activity of water extract of Spilanthes acmella flowers on rats. J Trop Med Plants. 2001;2:201-4.

77. Mondal AK, Parui S, Mandal S. Analysis of the free amino acid content in pollen of nine Asteraceae species of known allergenic activity. Ann Agr Env. 1998;5:1720.

78. Ahmed F, Selim MST, Das AK, Choudhuri MSK. Anti-inflammatory and antinociceptive activities of Lippia nodiflora Linn. Pharmazie. 2004;59(4):329-33.

79. Saraf DK, Dixit VK. Spilanthes acmella Murr. : Study on its extract spilanthol as larvicidal compound. Asian J Exp Sci. 2002;16(1-2):9-19.

80. Sharma A, Kumar V, Rattan RS, Kumar N, Singh B. Insecticidal toxicity of Spilanthol from Spilanthes acmella Murr. against Plutella xylostella. Am J Plant Sci. 2012;3(11):1568-72.

81. Tiwari KL, Jadhav SK, Joshi V. An update review on medicinal herb genus Spilanthes. J Chinese Integrative Med. 2011;9(11):1171-80. 
82. Pathak K. Herbal medicine: A rational approach in health care system. Int J Herbal Med. 2013;1(3):86-9.

83. Reshmi GR, Rajalakshmi R. Three new combinations in Acmella (Asteraceae: Heliantheae). Int J Trop Plant Res. 2016;3(1):67-9

84. Pareek A, Suthar M, Rathore GS, Bansal V. Feverfew (Tanacetum parthenium L.): A systematic review. Pharmacogn Rev. 2011;5(9):103-10.

85. Wu C, Chen F, Wang X, Kim HJ, He G, Haley-Zitlin V, et al. Antioxidant constituents in feverfew (Tanacetum parthenium) extract and their chromatographic quantification. Food Chemistry. 2006;96(2):220-7.

86. Pittler $\mathrm{MH}$, Ernst E. Feverfew for preventing migraine. Cochrane Database Syst Rev. 2004;(1):CD002286.

87. Saini DK, Kaushik P. Visiting eggplant from a biotechnological perspective: A review. Sci Hort. 2019;253:327-40.

88. Prashanth S, Pooja S, Suchetha KN, Vidya V. Radical scavenging and antioxidant activities of ethanolic and aqueous extract from the leaves of feverfew (Tanacetum parthenium L.) and a synthetic compound parthenolide. J Pharmacog Phytochem. 2015;4(1):223-7.

89. Subha D, Chandralega N, Geetha N. Phytochemical screening of Tanacetum parthenium L. (feverfew) leaves: An important medicinal plant. Int J Pharma Pharceutical Res. 2014;2(2):98-106

90. Sumner H, Salan U, Knight DW, Hoult JR. Inhibition of 5-lipoxygenase and cyclo-oxygenase in leukocytes by feverfew. involvement of sesquiterpene lactones and other components. Biochem Pharmacol. 1992;43(11):2313-20.

91. Collier HO, Butt NM, McDonald WJ, Saeed SA. Extract of feverfew inhibits prostaglandin biosynthesis. Lancet. 1980;2:922-3.

92. Brown AM, Edward CM, Davey MR, Power JB, Lowe KC. Pharmacological activity of feverfew(Tanacetum parthenium [L.] Schultz-Bip.) Assessment by inhibition of human polymorphonuclear leucocyte chemiluminescence in vitro. J Pharm Pharmacol. 1997;49(5):558-61.

Article History: Submission Date : 06-01-2020 ; Revised Date : 27-01-2020 ; Acceptance Date : 05-02-2020.

Cite this article: Saini I, Chauhan J, Kaushik P. Medicinal Value of Domiciliary Ornamental Plants of the Asteraceae Family. J Young Pharm. 2020;12(1):3-10. 